\title{
Effect of Diet and Aging on Human Fecal Microflora
}

\author{
Yoshimi Benno ${ }^{1}$ and Tomotari Mrtsuoka ${ }^{2,3}$ \\ ${ }^{1}$ Japan Collection of Microorganisms, ${ }^{2}$ Frontier Research Program, \\ RIKEN, Wako, Saitama 351-01 and \\ ${ }^{3}$ Nippon Veterinary and Animal Science University, \\ Musashino, Tokyo 180
}

(Received for publication, August 22, 1990)

Key words: fecal flora; high beef; high fiber; advanced age

The incidence of colon cancer varies widely throughout the world $(8,9)$. It has been demonstrated that the disease is much rarer in Africa, Asia, and South America than in Western Europe or North America (37). The reason for this variation is unclear but epidemiological studies, focusing on genetic, cultural, environmental and economic factors suggest that the diet, in particular an increased intake of fat and animal protein, is strongly correlated with the incidence of colon cancer $(19,36)$.

Epidemiologic studies $(7,31,36)$ also suggest that decreases in dietary fiber intake actually increase the incidence of several colonic disorders including: diverticular disease, cancer and constipation. Since some of the predominating bacteria in human fecal contents ferment various types of hemicelluloses (34), it would be of interest to determine the effects, if any, of dietary fiber on the human fecal flora.

It is widely known that the composition of fecal flora in healthy infants differed according to the mode of feeding $(2,18,23)$. Although taxonomic studies on Bifidobacterium species present in feces of babies have been carried out $(25,32)$, the bulk of anaerobes and aerobes from their feces have not been identified at the species level.

To address the aforementioned, the present studies were undertaken. Thus, the composition of the fecal flora of the following subjects were compared: (i) breastfed versus bottle-fed infants, (ii) rural Japanese with a low incidence of colon cancer, (iii) urban Canadians with a high incidence of colon cancer, (iv) Japanese volunteers given a high beef or a rice fiber diet (particularly brown rice), and (v) elderly Japanese in rural (Yuzurihara, Uenohara, Yamanashi Prefecture) and urban (Tokyo) areas of Japan, respectively.

\section{EFFECT OF FEEDING ON INFANTS FECAL FLORA}

Comparison of fecal flora in breast-fed and bottle-fed infants are shown in Table 1. These babies were aged from 28 to 46 days. Bifidobacteria were the 
predominant fecal bacteria in both groups. The differences of feeding (breast-fed or bottle-fed) influenced the fecal flora of infants. The microorganism presented at the highest percentage to total fecal bacteria in breast-fed $(62.2 \%$ with respect to total population) and bottle-fed $(33.3 \%$ ) groups was Bifidobacterium (designated as Bif.) breve. High percentages of Eubacterium (Eub.) aerofaciens, Bacteroides (B.) vulgatus, Escherichia (E.) coli, Enterococcus (En.) faecalis, En. faecium and clostridia in the bottle-fed infants were shown. These findings agreed with the results previously reported $(33,35)$.

\section{COMPOSITION OF FECAL FLORA IN HEALTHY ADULT MEN}

A total of 1829 isolates from 15 healthy adult men were identified as belonging to 29 genera and over 144 species (Table 2). Some anaerobic species of $B$. vulgatus, $B$. distasonis, B. fragilis, $B$. thetaiotaomicron, Fusobacterium $(F$.) mortiferum, Eub. aerofaciens, Eub. lentum, Bif. adolescentis, Bif. longum, Peptostreptococcus spp., Veillonella parvula, Clostridium (Cl.) innocuum, $\mathrm{Cl}$. paraputrificum, and $\mathrm{Cl}$. perfringens were recovered. These

Table 1. Comparison of fecal flora in breast-fed and bottle-fed infants $a$

\begin{tabular}{|c|c|c|c|c|}
\hline \multicolumn{3}{|c|}{ Breast-fed infants } & \multicolumn{2}{|c|}{ Bottle-fed infants } \\
\hline No. of samples & \multicolumn{2}{|c|}{35} & \multicolumn{2}{|l|}{35} \\
\hline No. of isolates & \multicolumn{2}{|c|}{1105} & \multicolumn{2}{|l|}{1604} \\
\hline $\begin{array}{l}\text { Identification } \\
\text { of isolates }\end{array}$ & \multicolumn{2}{|c|}{$\begin{array}{l}21 \text { genera and } \\
\text { more than } 103 \\
\text { species }\end{array}$} & \multicolumn{2}{|c|}{$\begin{array}{l}20 \text { genera and } \\
\text { more than } 97 \\
\text { species }\end{array}$} \\
\hline \multicolumn{5}{|l|}{ Rank } \\
\hline 1 & Bif. breve & 62.2 & Bif. breve & 33.3 \\
\hline 2 & Bif. bifidum & 14.7 & Eub. aerofaciens & 20.9 \\
\hline 3 & Bif. adolescentis & 11.2 & Bif. longum & 12.4 \\
\hline 4 & Bif. longum & 7.8 & B. vulgatus & 10.4 \\
\hline 5 & Eub. lentum & 0.4 & Bif. adolescentis & 8.4 \\
\hline 6 & B. distasonis & 0.2 & Bif. bifidum & 8.4 \\
\hline 7 & B. vulgatus & 0.2 & E. coli & 2.4 \\
\hline 8 & Eub. aerofaciens & 0.07 & B. distasonis & 1.1 \\
\hline 9 & B. ovatus & 0.05 & En. faecalis & 0.7 \\
\hline 10 & B. fragilis & 0.05 & En. faecium & 0.5 \\
\hline 11 & E. coli & 0.05 & $V$. parvula & 0.3 \\
\hline 12 & V. parvula & $<0.01$ & L. gasseri & 0.3 \\
\hline 13 & En. faecalis & $<0.01$ & $K$. pneumoniae & 0.3 \\
\hline 14 & $K$. pneumoniae & $<0.01$ & Cl. perfringens & 0.3 \\
\hline 15 & L. gasseri & $<0.01$ & Cl. paraputrificum & 0.1 \\
\hline 16 & En. faecium & $<0.01$ & Cl. difficile & 0.1 \\
\hline 17 & Cl. butyricum & $<0.01$ & Cl. sartanogoformum & 0.05 \\
\hline 18 & St. epidermidis & $<0.01$ & Cl. tertium & 0.05 \\
\hline 19 & St. aureus & $<0.01$ & St. epidermidis & $<0.01$ \\
\hline 20 & Cl. paraputrificum & $<0.01$ & St. aureus & $<0.01$ \\
\hline
\end{tabular}

$a$ Data were expressed as a percentage of total bacteria. B., Bacteroides; Bif., Bifidobacterium; C., Coprococcus; Cl. Clostridium; E., Escherichia; En., Enterococcus; Eub., Eubacterium; K., Klebsiella; L., Lactobacillus; S., Streptococcus; St., Staphylococcus; V., Veillonella. 
results in our study were similar to the data described previously $(13,21,28)$.

\section{EFFECT OF A HIGH BEEF DIET ON HUMAN FECAL FLORA}

The 762 isolates from nine rural Japanese (high fiber group) belonged to 23 genera and over 75 species or biovars, while the 618 isolates from eight urban Canadians (high beef group) represented 18 genera and over 66 species or biovars (4). Strict anaerobes were found in similar diversity in the feces of Japanese (13 genera, over 61 species or biovars) and urban Canadians (11 genera, over 55 species or biovars). Details of the relatively high percentage of anaerobes are given in Table 2. Most anaerobic bacteria belonged to the genera Bacteroides, Fusobacterium, Bifidobacterium, Eubacterium, Lactobacillus, Clostridium, Peptostreptococcus, and Veillonella. Bacteroides spp. were recovered in large percentages from both populations. The relative percentages of $B$. vulgatus, $B$. uniformis, the $B$. buccae/oris group, $C l$. innocuum and $C l$. ramosum were higher in the Canadians than in the Japanese; there were lower percentages of Eub. aerofaciens and Bif. adolescentis in the feces of the Canadians. The most prevalent facultative aerobes in either populations were Escherichia (E.) coli and Enterococcus faecalis.

The effect of a high beef diet on fecal flora of six healthy adult men was the increasing percentage (compared to the total bacterial population) of $B$. fragilis, $B$. uniformis, B. stercoris, Cl. paraputrificum, $C l$. innocuum and $C l$. ramosum and the decreasing percentages of Bif. adolescentis, Eub. aerofaciens and Bif. longum (Table 2).

Incidences of colon cancer in Western countries are up to eight times those in developing countries, where the fiber intake is generally higher $(6,7)$. While the incidence of colon cancer in Japan was the lowest in the world $(29,36)$, in Japanese immigrants it increases to that of the host country by the second or third generations $(5,19)$. Dietary factors, particularly a high intake of total fat and a relatively low intake of certain dietary fibers, play important roles in colon cancer etiology $(7,30)$.

It is widely known that the fecal flora are strongly influenced by the diet. One line of evidence concerning the effect of diet has been reported from comparisons of the fecal flora of populations that habitually consume different diet. The purpose of this study was to detect any differences in the fecal flora between high meat eaters and high fiber eaters, which might be correlated with the high incidence of colon cancer in urban Canadians and the low incidence in rural Japanese. Several studies $(13,14,26)$ have demonstrated that certain significant differences in the composition of the fecal flora between high- and low-risk populations of colon cancer are not apparent. The present investigation showed that the fecal flora, represented by anaerobic gram-positive nonsporeforming bacteria, in particular, Bifidobacterium spp. and Eubacterium spp., is dominant in rural Japanese.

Koornhof et al (21) showed that clostridial species are more numerous in the fecal flora of Africans than of patients with colonic polyps. On the other hand, $\mathrm{Cl}$. paraputrificum was common in feces from subjects in England, Scotland, and U.S.A., but rare in the samples from Hong Kong, Uganda, and Japan (10). 
Table 2. Effects of high fat/high

\begin{tabular}{|c|c|c|c|c|c|c|}
\hline & \multicolumn{2}{|l|}{ Healthy adults } & \multicolumn{2}{|c|}{$\begin{array}{c}\text { Rural Japanese } \\
\text { (Low fat \& high fiber) }\end{array}$} & \multicolumn{2}{|c|}{$\begin{array}{c}\text { Urban Canadians } \\
\text { (High fat \& low fiber) }\end{array}$} \\
\hline $\begin{array}{l}\text { No. of } \\
\text { samples }\end{array}$ & \multicolumn{2}{|l|}{15} & \multicolumn{2}{|l|}{9} & \multicolumn{2}{|l|}{8} \\
\hline $\begin{array}{l}\text { No. of } \\
\text { isolates }\end{array}$ & \multicolumn{2}{|l|}{1829} & \multicolumn{2}{|l|}{762} & \multicolumn{2}{|l|}{618} \\
\hline $\begin{array}{l}\text { Identifi- } \\
\text { cation of } \\
\text { isolates }\end{array}$ & \multicolumn{2}{|c|}{$\begin{array}{l}29 \text { genera and } \\
\text { more than } 144 \\
\text { species }\end{array}$} & \multicolumn{2}{|c|}{$\begin{array}{l}23 \text { genera and } \\
\text { more than } 75 \\
\text { species }\end{array}$} & \multicolumn{2}{|l|}{$\begin{array}{l}18 \text { genera and } \\
\text { more than } 66 \\
\text { species }\end{array}$} \\
\hline \multicolumn{7}{|l|}{ Rank } \\
\hline 1 & B. vulgatus & 27.8 & Eub. aerofaciens & 25.1 & B. vulgatus & 33.3 \\
\hline 2 & Bif. adolescentis & 14.1 & Bif. adolescentis & 15.8 & B. distasonis & 9.8 \\
\hline 3 & B. distasonis & 10.9 & B. vulgatus & 15.8 & B. ovatus & 7.5 \\
\hline 4 & Eub. aerofaciens & 8.9 & B. ovatus & 7.1 & B. uniformis & 7.5 \\
\hline 5 & B. thetaiotaomicron & 5.2 & B. distasonis & 6.3 & B. buccae/oris group & 6.7 \\
\hline 6 & Bif. longum & 5.2 & B. fragilis & 6.3 & B. fragilis & 5.2 \\
\hline 7 & B. buccae/oris group & 3.6 & $P$. productus & 3.9 & Bif. adolescentis & 5.2 \\
\hline 8 & B. uniformis & 3.6 & Bif. longum & 3.2 & Bif. bifidum & 5.2 \\
\hline 9 & B. ovatus & 2.8 & Bif. bifidum & 2.5 & Eub. aerofaciens & 5.2 \\
\hline 10 & $P$. prevotii & 2.8 & $R$. lactaris & 2.5 & B. thetaiotaomicron & 3.3 \\
\hline 11 & Eub. rectale & 2.2 & $F$. varium & 1.9 & Eub. lentum & 3.3 \\
\hline 12 & Bif. bifidum & 2.2 & Eub. rectale & 1.9 & P. productus & 2.0 \\
\hline 13 & C. comes & 1.8 & S. intermedius & 1.9 & $F$. varium & 1.7 \\
\hline 14 & $B$. veroralis & 1.4 & B. splanchnicus & 1.6 & Eub. rectale & 1.3 \\
\hline 15 & R. lactaris & 1.4 & F. mortiferum & 1.6 & Cl. innocuum & 0.8 \\
\hline 16 & $P$. productus & 1.1 & B. thetaiotaomicron & 1.2 & F. mortiferum & 0.7 \\
\hline 17 & $F$. varium & 0.9 & Eub. lentum & 1.2 & Cl. ramosum & 0.2 \\
\hline 18 & P. micros & 0.7 & B. buccae/oris group & 0.04 & E. coli & 0.05 \\
\hline 19 & B. fragilis & 0.5 & E. coli & 0.03 & En. faecalis & $<0.01$ \\
\hline 20 & $F$. mortiferum & 0.5 & En. faecalis & $<0.01$ & En. faecium & $<0.01$ \\
\hline
\end{tabular}

Mastromarino et al (22) also indicated that the numbers and incidence of clostridia, i.e., $\mathrm{Cl}$. butyricum, $\mathrm{Cl}$. innocuum, $\mathrm{Cl}$. indolis, $\mathrm{Cl}$. paraputrificum, $\mathrm{Cl}$. tertium, and $\mathrm{Cl}$. sartanogoformum, constitute a greater percentage of the fecal flora in patients with colon cancer. These clostridia have been shown to be capable of exhibiting nuclear dehydrogenation, an important reaction in the formation of carcinogens from bile acids $(11,17)$. In this study, an increasing percentage of $\mathrm{Cl}$. innocuum, $\mathrm{Cl}$. ramosum, and $\mathrm{Cl}$. paraputrificum with a high beef intake was observed. High recovery of these microorganisms lend support to the findings of Hill and his colleagues $(1,20)$.

\section{EFFECT OF DIETARY FIBER ON HUMAN FECAL FLORA}

Comparison of the fecal flora of five healthy adult men on a polished rice or brown rice diet for 14 days is shown in Table 2. By genera, the same strict anaerobes, facultative anaerobes, and aerobes were present in the feces throughout this 
fiber diets on human fecal flora $a$

\begin{tabular}{|c|c|c|c|c|c|}
\hline \multicolumn{2}{|l|}{ High beef diet } & \multicolumn{2}{|c|}{ Polished rice } & \multicolumn{2}{|l|}{ Brown rice } \\
\hline \multicolumn{2}{|l|}{6} & \multicolumn{2}{|l|}{5} & \multicolumn{2}{|l|}{5} \\
\hline \multicolumn{2}{|l|}{548} & \multicolumn{2}{|l|}{404} & \multicolumn{2}{|l|}{338} \\
\hline \multicolumn{2}{|c|}{$\begin{array}{l}20 \text { genera and } \\
\text { more than } 71 \\
\text { species }\end{array}$} & \multicolumn{2}{|c|}{$\begin{array}{l}20 \text { genera and } \\
\text { more than } 62 \\
\text { species }\end{array}$} & \multicolumn{2}{|c|}{$\begin{array}{l}17 \text { genera and } \\
\text { more than } 46 \\
\text { species }\end{array}$} \\
\hline B. vulgatus & 27.3 & B. vulgatus & 28.1 & B. vulgatus & 27.1 \\
\hline B. fragilis & 10.0 & B. thetaiotaomicron & 7.2 & Bif. adolescentis & 11.0 \\
\hline B. distasonis & 10.0 & Bif. longum & 7.2 & $R$. gnavus & 8.8 \\
\hline B. uniformis & 8.0 & Eub. aerofaciens & 7.2 & B. uniformis & 7.0 \\
\hline B. buccae/oris group & 7.0 & B. distasonis & 5.7 & B. distasonis & 7.0 \\
\hline B. veroralis & 7.0 & B. fragilis & 5.7 & $P$. magnus & 7.0 \\
\hline F. mortiferum & 7.0 & Bacteroides sp. A & 4.6 & B. fragilis & 5.6 \\
\hline B. stercoris & 6.5 & Eub. lentum & 4.6 & B. thetaiotaomicron & 4.3 \\
\hline P. productus & 4.5 & Eub. rectale & 4.6 & Eub. rectale & 4.3 \\
\hline Bif. adolescentis & 2.7 & $P$. anaerobius & 4.6 & B. ovatus & 3.5 \\
\hline C. comes & 2.7 & B. ovatus & 3.6 & B. buccae/oris group & 3.5 \\
\hline Eub. lentum & 2.2 & B. splanchnics & 3.6 & Bif. longum & 3.5 \\
\hline$R$. gnavus & 2.2 & B. uniformis & 3.6 & $P$. productus & 1.6 \\
\hline Eub. aerofaciens & 1.2 & Bif. adolescentis & 1.8 & Bacteroides sp. A & 1.4 \\
\hline Eub. rectale & 1.0 & P. prevotii & 1.8 & Cl. innocuum & 0.9 \\
\hline Cl. paraputrificum & 0.2 & Cl. ramosum & 1.4 & Eub. aerofaciens & 0.9 \\
\hline Cl. innocuum & 0.2 & P. magnus & 0.9 & Eub. lentum & 0.7 \\
\hline Bif. longum & 0.2 & $R$. gnavus & 0.9 & $P$. anaerobius & 0.4 \\
\hline Bif. bifidum & 0.2 & Me. elsdenii & 0.7 & $V$. parvula & 0.4 \\
\hline Cl. ramosum & 0.02 & Cl. innocuum & 0.7 & En. faecalis & 0.2 \\
\hline
\end{tabular}

study. A total of 404 isolates from the five persons given a polished rice diet were identified as belonging to 20 genera and over 62 species. A total of 338 isolates from the subjects on a brown rice diet were classified into 17 genera and over 46 species. The results showed that the total bacteria had decreased for the brown rice diet.

At day 14 of the brown rice diet, an increasing percentage of Bif. adolescentis, Ruminococcus $(R$.) gnavus and Peptostreptococcus magnus were observed, whereas the percentage of Eub. aerofaciens and $E$. coli decreased. Low percentage of all clostridia and low incidences of $\mathrm{Cl}$. paraputrificum and $\mathrm{Cl}$. perfringens were observed for the brown rice diet.

There have been few studies on the effect of fiber intake on the hrman fecal flora. Drasar et al (12) and Moore et al (27) found no significant differences in numbers of fecal flora in volunteers on a high fiber diet. On the other hand, Fuchs et al (16) noted a significantly increasing number of total bacteria with a high 
Table 3. Comparison of fecal flora of elderly persons in rural and urban areas of Japan ${ }^{a}$

\begin{tabular}{|c|c|c|c|c|c|c|}
\hline & \multicolumn{2}{|l|}{ Healthy adults } & \multicolumn{2}{|c|}{ Urban elderly persons } & \multicolumn{2}{|c|}{ Rural elderly persons } \\
\hline No. of samples & 15 & & 15 & & 15 & \\
\hline No. of isolates & 1829 & & 1496 & & 1284 & \\
\hline $\begin{array}{l}\text { Identification } \\
\text { of isolates }\end{array}$ & $\begin{array}{l}29 \text { genera and } \\
\text { more than } 144 \\
\text { species }\end{array}$ & & $\begin{array}{l}25 \text { genera and } \\
\text { more than } 92 \\
\text { species }\end{array}$ & & $\begin{array}{l}25 \text { genera and } \\
\text { more than } 81 \\
\text { species }\end{array}$ & \\
\hline \multicolumn{7}{|l|}{ Rank } \\
\hline 1 & B. vulgatus & 27.8 & B. vulgatus & 25.8 & B. vulgatus & 31.8 \\
\hline 2 & Bif. adolescentis & 14.1 & B. buccae/oris group & 20.5 & Eub. aerofaciens & 11.8 \\
\hline 3 & B. distasonis & 10.9 & Eub. aerofaciens & 12.9 & B. distasonis & 6.3 \\
\hline 4 & Eub. aerofaciens & 8.9 & $B$. distasonis & 7.6 & Eub. rectale & 6.3 \\
\hline 5 & B. thetaiotaomicron & 5.2 & B. thetaiotaomicron & 7.6 & B. fragilis & 5.0 \\
\hline 6 & Bif. longum & 5.2 & Eub. lentum & 4.0 & Selenomonas sp. & 5.0 \\
\hline 7 & B. buccae/oris group & 3.6 & Eub. rectale & 3.2 & B. ovatus & 4.0 \\
\hline 8 & B. uniformis & 3.6 & B. fragilis & 2.6 & B. stercoris & 4.0 \\
\hline 9 & $B$. ovatus & 2.8 & $F$. varium & 2.6 & M. multiacidus & 4.0 \\
\hline 10 & P. prevotii & 2.8 & P. magnus & 2.6 & Bif. adolescentis & 4.0 \\
\hline 11 & Eub. rectale & 2.2 & P. productus & 2.6 & P. productus & 4.0 \\
\hline 12 & Bif. bifidum & 2.2 & B. ovatus & 2.1 & F. mortiferum & 3.2 \\
\hline 13 & C. comes & 1.8 & B. stercoris & 1.3 & $F$. varium & 2.5 \\
\hline 14 & B. veroralis & 1.4 & $R$. gnavus & 1.3 & Bif. bifidum & 2.0 \\
\hline 15 & $R$. lactaris & 1.4 & Cl. ramosum & 1.0 & Bif. longum & 2.0 \\
\hline 16 & $P$. productus & 1.1 & Bif. adolescentis & 0.8 & $R$. gnavus & 2.0 \\
\hline 17 & $F$. varium & 0.9 & Bif. longum & 0.6 & B. buccae/oris group & 1.5 \\
\hline 18 & P. micros & 0.7 & F. mortiferum & 0.5 & B. thetaiotaomicron & 1.2 \\
\hline 19 & Cl. innocuum & 0.3 & $P$. magnus & 1.2 & P. magnus & 1.2 \\
\hline 20 & F. mortiferum & 0.5 & E. coli & 0.2 & Eub. lentum & 0.9 \\
\hline
\end{tabular}

a See the footnote of Table 2 .

fiber intake. In this study, although a reduction of the genus Clostridium was observed in all the subjects on a brown rice intake, marked differences at the species level of the genus were not found. Our results with the rice fiber diet were also comparable to the lower incidence of $\mathrm{Cl}$. perfringens among Seventh-Day Adventists (15).

\section{COMPARISON OF THE FECAL FLORA OF ELDERLY PERSONS IN RURAL AND URBAN AREAS OF JAPAN}

Comparison of the fecal flora of elderly persons in rural and urban areas of Japan is given in Table 3. A total of 1496 isolates from 15 elderly urbanites ranging in age from 65 to 76 years were classified into 25 genera and over 92 species. A total of 1284 isolates from 15 elderly persons, ranging in age from 75 to 92 years, in the rural area were identified as belonging to 25 genera and over 81 species.

Higher percentages of the $B$. buccaeloris group, B. fragilis, $F$. varium, $R$. gnavus, $C l$. ramosum, and $\mathrm{Cl}$. innocuum were found in feces of the urban elderly persons compared with the healthy adults, whereas the percentage of Bif. adolescentis and Bif. 
longum in elderly persons in the urban area were markedly decreased. Percentages of Bif. adolescentis and Bif. longum, but not B. thetaiotaomicron, in rural elderly persons were higher than those in elderly urbanites.

Mitsuoka et al (25) demonstrated that a higher incidence of Bif. adolescentis and a lower incidence of Bif. longum in elderly persons reflected the characteristic composition of fecal Bifidobacterium spp. Mitsuoka and Hayakawa (24) also reported that the number and incidence of $\mathrm{Cl}$. perfringens in elderly persons were higher than those in healthy adults. Results of our study are in very good agreement with these findings.

Elderly persons in Yuzurihara, an area whose inhabitants tend to be longlived, have a higher intake of dietary fiber than elderly residents of the Tokyo area (3). The percentage of Bif. adolescentis and Bif. longum in rural elderly persons was higher than those in elderly urbanites. This finding suggests that with advancing age the fecal flora can be modified by a higher intake of dietary fiber.

\section{REFERENCES}

(1) Aries, V., J.S. Crowther, B.S. Drasar, M.J. Hill, and W.E.O. Williams. 1969. Bacteria and the aetiology of cancer of the large bowel. Gut 10: 334-335.

(2) Benno, Y., K. Sawada, and T. Mitsuoka. 1984. The intestinal microflora of infants: composition of fecal flora in breast-fed and bottle-fed infants. Microbiol. Immunol. 28: 975-986.

(3) Benno, Y., K. Endo, T. Mizutani, Y. Namba, T. Komori, and T. Mitsuoka. 1989. Comparison of fecal microflora of elderly persons in rural and urban areas of Japan. Appl. Environ. Microbiol. 55: 1100-1105.

(4) Benno, Y., K. Suzuki, K. Suzuki, K. Narisawa, W.R. Bruce, and T. Mitsuoka. 1986. Comparison of the fecal microflora in rural Japanese and urban Canadians. Microbiol. Immunol. 30: $521-531$.

(5) Buell, I., and J.E. Dunn, Jr. 1965. Cancer mortality among Japanese issei and nisei of California. Cancer 18: 656-664.

(6) Burkit, D.P. 1971. Epidemiology of cancer of the colon and rectum. Cancer 28: 3-13.

(7) Burkit, D.P. 1980. Fiber in the etiology of colorectal cancer, p. 13-18. In S. Winawer, D. Schottenfeld, and P. Sherlock (eds.), Colorectal cancer: prevention, epidemiology and screening, Raven Press, New York.

(8) Daves, J.A.P., J. Knowelden, and B.A. Wilson. 1965. Incidence rates of cancer in Kyadondo County, Uganda 1954-60. J. Natl. Cancer Inst. 35: 789-795.

(9) Doll, R. 1969. The geographic distribution of cancer. Br. J. Cancer 23: 1-8.

(10) Drasar, B.S., P. Goddard, S. Heaton, S. Peach, and B. West. 1976. Clostridium isolated from feces. J. Med. Microbiol. 9: 63-71.

(11) Drasar, B.S., and M.J. Hill. 1974. Human intestinal flora. Academic Press Inc., London.

(12) Drasar, B.S., D.J.A. Jenkins, and J.H. Cummings. 1976. The influence of a diet rich in wheat fiber on the human faecal flora. J. Med. Microbiol. 9: 423-431.

(13) Finegold, S.M., H.R. Attebery, and V.L. Sutter. 1974. Effect of diet on human fecal flora: comparison of Japanese and American diets. Am. J. Clin. Nutr. 27: 1456-1469.

(14) Finegold, S.M., and V.L. Sutter. 1978. Fecal flora in different populations with special reference to diet. Am. J. Clin. Nutr. 31: S116-S122.

(15) Finegold, S.M., V.L. Sutter, P.T. Sugihara, H.A. Elder, S.M. Lehman, and R.L. Phillips. 1977. Fecal microflora in Seventh-Day Adventist populations and control subjects. Am. J. Clin. Nutr. 30: 1781-1792.

(16) Fuchs, H., S. Dorfman, and M.H. Floch. The effect of dietary fiber supplementation in man. II. Alteration in fecal physiology and bacterial flora. Am. J. Clin. Nutr. 29: 1443-1447. 
(17) Goddard, P., F. Fernandez, B. West, M.J. Hill, and P. Barnes. 1975. The nuclear dehydrogenation of steroids by intestinal bacteria. J. Med. Microbiol. 8: 429-435.

(18) Haenel, H., W. Muller-Beuthow, and F.K. Grutte. 1970. Zur fakalen Mikrookologie des Sauglings in Abhangigkeit von der Ernahrung: Zusammen setzung der Mikroflora sowie Vorkommen der Lactobacillus bifidus-Typen. Zentralbl. Bakteriol. I. Abt. Orig. 115: 333-347.

(19) Haenszel, W., J.W. Berg, M. Segi, M. Kurihara, and T. Locke. 1973. Large bowel cancer in Hawaiian Japanese. J. Natl. Cancer Inst. 51: 1765-1779.

(20) Hill, M.J., B.S. Draser, V. Aries, J.C. Crowther, G. Hawksworth, and R.E.O. Williams. 1971. Bacteria and aetiology of cancer of the large bowel. Lancet $\mathbf{i}$ : 95-100.

(21) Koornhof, H.J., N.J. Richardson, D.M. Wall, and W.E.C. Moore. 1980. Fecal bacteria in South African rural blacks and other population groups. Isr. J. Med. Sci. 15: 335-340.

(22) Mastromarino, A.J., B.S. Reddy, and E.L. Wynder. 1978. Fecal profiles of anaerobic microflora of large bowel cancer patients and patients with nonhereditary large bowel polyps. Cancer Res. 38: 4458-4462.

(23) Mitsuoka, T. 1982. Recent trends in research on intestinal flora. Bifidobacteria Microflora 1: 3-24.

(24) Mitsuoka, T., and K. Hayakawa. 1972. Die Faekalflora bei Menschen. I. Mitteilung: die Zusammensetzung der Faecaslflora der verschedenen Altersgruppen. Zentralbl. Bakteriol. Mikrobiol. Hyg. I Abt. Orig. A223 : 333-342.

(25) Mitsuoka, T., K. Hayakawa, and N. Kimura. 1974. Die Faekalflora bei Menschen. II. Mitteilung: die Zusammensetzung der Bifidobakterienflora der verschiedenen Altersgruppen. Zentralbl. Bakteriol. Mickrobiol. Hyg. I Abt. Orig. A226: 469-478.

(26) Moore, W.E.C., E.P. Cato, I.J. Good, and L.V. Holdeman. 1978. Some current concepts in intestinal bacteriology. Am. J. Clin. Nutr. 31: S33-S42.

(27) Moore, W.E.C., E.P. Cato, I.J. Good, and L.V. Holdeman. 1981. The effect of diet on the human fecal flora, p. 11-24. In W.R. Bruce, P. Correa, M. Lipkin, S.R. Tannebaum, and T.D. Wilkins (eds.), Banbury Report 7, Gastrointestinal cancer: endogenous factors, Cold Spring Harbor Laboratory.

(28) Moore, W.E.C., and L.V. Holdeman. 1974. Human fecal flora: the normal flora of 20 Japanese-Hawaiians. Appl. Microbiol. 27: 961-976.

(29) Narasaka, T., H. Watanabe, S. Yamagata, A. Munakata, T. Tajima, and F. Matsunaga. 1975. Statistical analysis of diverticulosis of the colon. Tohoku J. Exp. Med. 115: 271-276.

(30) Reddy, B.S., L.A. Cohen, G.D. McCoy, P. Hill, J.H. Weisburger, and E.L. Wynder. 1980. Nutrition and its relationship to cancer. Adv. Cancer Res. 32: 237-345.

(31) Reddy, B.S., J.H. Weisburger, and E.L. Wynder. 1975. Effects of high risk and low risk diets for colon carcinogenesis on fecal microflora and steroids in man. J. Nutr. 105: 878-884.

(32) Reuter, G. 1963. Vergleichende Untersuchungen uber die Bifidus-Flora in Sauglings- und Erwachsenstuhl. Zentralbl. Bakteriol. I. Abt. Orig. 191: 486-507.

(33) Rotimi, V.O., and B.I. Duerden. 1986. The development of the bacterial flora in normal neonates. J. Med. Microbiol. 14 : 51-62.

(34) Salyers, A.A., S.E. West, J.R. Vercellott, and T.D. Willkins. 1977. Fermentation of mucins and plant polysaccharides by anaerobic bacteria from the human colon. Appl. Environ. Microbiol. 34: 529-533.

(35) Stark, P.L., and A. Lee. 1982. Clostridia isolated from the feces of infants during the first year of life. J. Med. Microbiol. 15: 189-203.

(36) Wynder, E.L., T. Kajitani, S. Ishikawa, H. Dodo, and A. Takano. 1969. Environmental factors of cancer of the colon and rectum. II. Japanese epidemiological data. Cancer 23: 12101220.

(37) Wynder, E.L., and B.S. Reddy. 1983. Dietary fat and fiber and colon cancer. Semin. Oncol. 10: 264-272. 